\title{
RANCANG BANGUN SISTEM INFORMASI AKUNTANSI PENJUALAN DENGAN MODEL WATERFALL BERBASIS JAVA DESKTOP
}

\author{
${ }^{1}$ Sistem Informasi Akuntansi \\ Universitas Bina Sarana Informatika \\ www.bsi.ac.id \\ nurulmuthia1410@gmail.com \\ ${ }^{2}$ Sistem Informasi \\ Universitas Bina Sarana Informatika \\ www.bsi.ac.id \\ hilda.ham@bsi.ac.id \\ ${ }^{3}$ Teknik Informatika \\ STMIK Antar Bangsa \\ www.antarbangsa.ac.id \\ argi.puspita@gmail.com \\ ${ }^{4}$ Sistem Informasi Akuntansi \\ Universitas Bina Sarana Informatika \\ www.bsi.ac.id \\ ade.afr@bsi.ac.id
}

Nurul Muthia1; Hilda Amalia' ${ }^{2}$ Ari Puspita ${ }^{3}$; Ade Fitria Lestari4

\begin{abstract}
Every business entity is required to be able to improve their services to customers. With good service it will increase customer satisfaction so that it ultimately increases profits from the business entity itself. To be able to improve service to customers, business entities must be able to present an efficient and accurate sales transaction process. For this reason, sales information system design is needed. Sales accounting information system can streamline the sales transaction process and can produce sales reports that are more accurate and timely and able to record accounting transactions in a short time. Timely and accurate sales reports are needed for the decision making process for business entity owners. The research objective is to develop software using the waterfall device development method, so that it can produce software that is able to improve sales system work and increase profits. The design results of the sales information system using the waterfall method can reduce errors caused by human factors (avoiding human error), avoiding the combination of data entry and presentation of sales reports presented in a fast and precise time so as to help the owner to make the decision making process.
\end{abstract}

Keywords: Sales Information System, Waterfall Method, Java Desktop

Intisari- Setiap entitas bisnis diwajibkan untuk dapat meningkatkan layanan mereka kepada pelanggan. Dengan layanan yang baik itu akan meningkatkan kepuasan pelanggan sehingga pada akhirnya meningkatkan laba dari entitas bisnis itu sendiri. Untuk dapat meningkatkan layanan kepada pelanggan, entitas bisnis harus dapat menyajikan proses transaksi penjualan yang efisien dan akurat. Untuk alasan ini, desain sistem informasi penjualan diperlukan. Sistem informasi akuntansi penjualan dapat merampingkan proses transaksi penjualan dan dapat menghasilkan laporan penjualan yang lebih akurat dan tepat waktu dan mampu merekam transaksi akuntansi dalam waktu yang singkat. Laporan penjualan yang tepat waktu dan akurat diperlukan untuk proses pengambilan keputusan bagi pemilik entitas bisnis. Tujuan penelitian adalah melakukan pengembangan perangkat lunak dengan menggunakan metode pengembangan perangkat waterfall, sehingga dapat menghasilkan perangkat lunak yang mampu meningkatkan kerja sistem penjualan dan meningkatkan keuntungan. Hasil rancang bangun sistem informasi penjualan dengan menggunakan metode waterfall ini dapat mengurangi kesalah-kesalahan yang disebabkan oleh faktor manusia (human error), menghindari dari kerangkapan entry data dan penyajian laporan penjualan disajikan dalam waktu yang cepat dan tepat sehingga membantu pemilik untuk melakukan proses pengambilan keputusan.

Kata Kunci: Sistem Informas, Penjualan, Metode Waterfall, Java Dekstop 


\section{PENDAHULUAN}

Setiap badan usaha yang didirikan memiliki tujuan untuk mendapatkan laba yang banyak (Amalia, Lestari, \& Puspita, 2017). Keinginan untuk mendapatkan laba dalam jumlah yang besar merupakan suatu upaya untuk suatu badan usaha untuk tetap beroperasi dengan baik. Salah satu cara untuk medapatkan laba dengan jumlah yang besar yakni meningkatkan volume transaksi penjualan badan usaha tersebut. Penjualan secara umum yaitu sebagai sebuah usaha atau langkah konkrit yang dilakukan untuk memindahkan suatu produk, baik itu berupa barang ataupun jasa, dari produsen kepada konsumen sebagai sasarannya (Noor Hasan, 2014).

Untuk mampu meningkatkan volume transaksi penjualannya, suatu badan usaha harus mempunyai sistem penjualan yang baik, yakni suatu sistem yang cepat, tepat dan efisien dalam pengelolaannya. Sistem penjualan secara konvensional yang dilakukan badan usaha sudah tidak dapat lagi diterapkan karena dapat menimbulkan kesalahan pencatatan dan rentan terhadap tindakan kecurangan operasional penjualan (Widiati, 2017). Dalam pengunaan sistem manual memiliki resiko kesalahan perhitungan data dan kehilangan data lebih besar (Amalia , Ferdira, \& Anggaraini, 2017). Selain itu pengggunaan sistem penjualan manual juga mengakibatkan proses transaksi berjalan lambat sehingga mempengaruhi kenyamanan berberlanja customer. Tentu hal ini akan mempengaruhi tingkat kepecayaan dan loyalitas customer untuk datang dan berbelanja kembali.

Permasalahan lain dari sistem manua adalah laporan penjualan disajikan dalam waktu yang cukup lama, serta informasi yang dihasilkan sering tidak akurat karena riskan untuk dimanipulasi (Ramadhan \& Purwandari, 2018). Suatu laporan diperlukan oleh pemilik usaha yang akan digunakan untuk melakukan proses pengambilan keputusan bagi usaha itu sendiri. Pencatatan transaksi secara manual sering mengakibatkan kesalahan sehingga laporan menjadi tidak akuarat (Azwanti, 2017). Laporan yang tidak akurat akan membuat proses pengambilan keputusan terhambat dan juga salah dalam dalam mengambil keputusan sehingga dapat merugikan badan usaha dan dapat mengakibatkan pula keangkrutan usaha (Amalia, Lestari, \& Puspita, 2017). Untuk itu perlu dalam pengolahan transaksi penjualan dan pencatatan transaski akuntansi perlu ditingkatkan lagi dengan menggunakan sistem yang terkomputerisasi. Yakni perubahan dari pengunaan aplikasi excel ke penggunakan program aplikasi penjualan.
Sehingga masalah dalam sistem penjualan manual dapat teratasi.

Sistem informasi penjualan berbasis desktop mampu mempercepat transaksi dan mempermudah proses pengambilan keputusan dan mempercepat pembuatan laporan (Widayanti, Ariebowo, \& Maknunah, 2018). Dalam pembuatan aplikasi program yang diperlukan untuk sistem informasi penjualan maka diperlukan metode yang efektik dan efisien dalam pengembangannya. Salah satu metode yang sudah banyak digunakan yaitu metode waterfall. Metode waterfall memberikan pendekatan-pendekatan sistematis dan berurutan bagi pengembangan sistem informasi, juga mempunyai beberapa tahapan-tahapan model didalam nya (Susanti, 2016). Dari penelitian sebelumnya metode waterfall merupakan metode pengembangan perangkat lunak yang dirasa cukup efektif untuk pengembangan suatu aplikasi. Penelitian ini bertujuan membangun suatu sistem informasi penjualan dengan menggunakan metode waterfall.

\section{BAHAN DAN METODE}

Penelitian ini melakukan tahapan penelitian yang digunakan seperti Gambar 1 . Analisa kebutuhan dibuat dengan cara mengumpulkan semua data dan informasi mengenai sistem lama dan membuat rancangan kebutuhan mengenai sistem penjualan yang akan dirancang dengan menggunakan metode Waterfall. Data dan informasi mengenai sistem lama diperoleh dari beberapa cara yaitu dengan melakukan tanya jawab atau wawancara merupakan metode analisis dan pengumpulan data dengan dilakukan proses Tanya jawab dengan narasumber (Wijaya \& Irawan, 2018) dengan customer, pemilik dan pelaku proses penjualan itu sendiri. Dari proses Tanya jawab diperoleh masalah-masalah yang dihadapi oleh badan usaha dan memperoleh tentang gambaran mengenai sistem informasi penjualan yang diharapkan dapat menyelesaikan permasalah sistem penjualan manual. Selanjutnya melakukan Observasi, Observasi adalah mengadakan pengamatan langsung pada bagian penjualan untuk mengamati keadaan sebenarnya dari obyek yang akan diteliti guna mendapat memperoleh data sesungguhnya dari perusahaan(Ishak \& Widyastuti, 2018). Untuk memperoleh gambaran rancang bangun yang akan diterapkan maka dilakukan proses pengamatan terhadap sistem penjualan yang saat ini diterapkan dan pengamatan sistem terkomputerasisi yang akan diterapkan dan melakukan analisa dokumen. Sehingga diperoleh rancang bangun yang sesuai untuk perusahaan. 


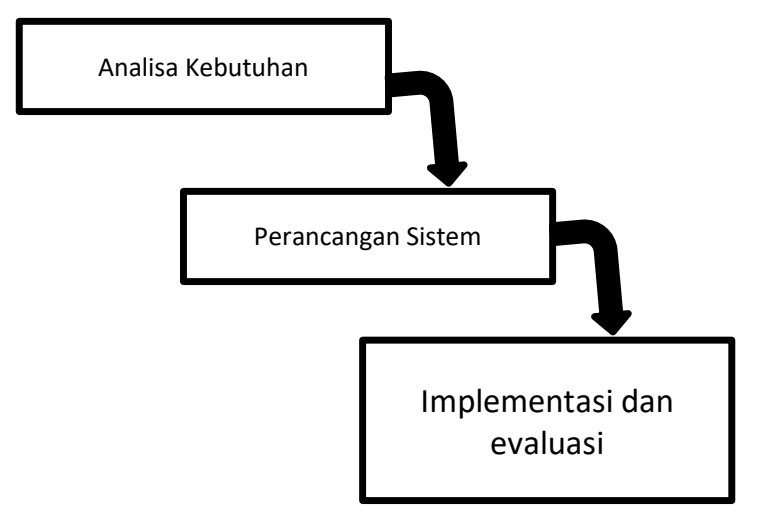

Gambar 1. Tahapan penelitian yang digunakan

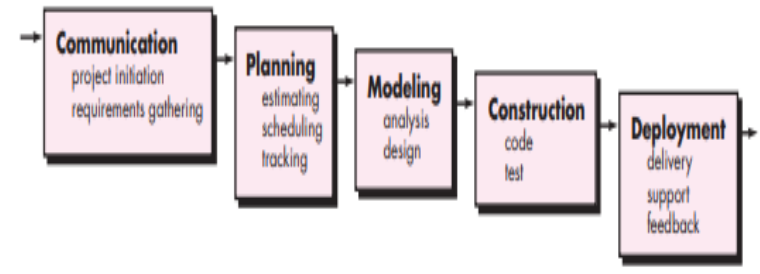

Sumber: (Pressman, 2010)

Gambar 2 Model Waterfall

Perancangan sistem pada penelitian ini menggunakan metode UML (Unifed Modeling Language) untuk membuat Activity Diagram, Use Case Diagram, Sequence Diagram dan Deployment Diagram serta menggunakan ERD dan LRS. Pada tahap pembuatan kode program peneliti menggunakan bahasa pemrograman java dan MYSQL yang dituangkan kedalam software NetBeans IDE 8.1 dengan menggunakan XAMPP sebagai web server.

Implementasi dan Evaluasi, dalam melakukan pemrograman peneliti melakukan pengujian terhadap kode-kode program untuk memastikan kebenaran program tersebut. Pengujian ini dilakukan untuk mencari kesalahan yang ditimbulkan karena salah tulisan atau kesalahan pemrograman. Dalam pengujian sistem penjualan, penelitian menggunakan metode black box testing. Hal ini dilakukan untuk mencari posisi kesalahan (error) dan memastikan keluaran yang dihasilkan sesuai yang diinginkan.

\section{HASIL DAN PEMBAHASAN}

Rancang Bangun Sistem Penjualan menggunakan metode waterfall (Gambar 2). Gambar 2 adalah model waterfall yang digunakan tahapan pertama yakni communication, dengan cara melakukan penentuan awal proyek dan persyaratan yang dibutuhkan dalam penelitian ini dilakukan metode pengumpulan data. Tahap ke dua adalah planning, yaitu melakukan perencanaan dalam penelitian ini perencanaan dilakukan dengan melakukan analisa kebutuhan sistem. Tahap ketiga yaitu modeling dengan melakukan analisa design menggunakan diagram UML. Tahap keempat contruction yaitu melakukan pengetikkan kode program dan testing program. Tahapan terakhir yaitu Development yaitu feedback dari program berdasarkan testing yang dilakukan.

A. Communication

Pada tahapan comunication mempertemukan antara customer untuk memahami kebutuhan dari sistem informasi yang diinginkan. Pada penelitian ini dilakukan Tanya jawab mengenai sistem informasi yang diinginkan oleh customer atau pemilik perusahan.

\section{B. Planning}

Pada tahapan planning dilakukan perencanaan mengenai sistem informasi yang diinginkan. Perencanaan mengenai apa saja yang dibutuhkan dan apa saja yang mampu dilakukan oleh sistem informasi yang akan dikembangkan. Dalam penelitian ini dilakukan perencanaan dengan membuatkan analisa kebutuhan sistem. Pada sistem yang dibangun admin dapat mengelola data pengguna meliputi menambah, mengubah, mencari dan menghapus data pengguna. Admin dapat mengelola data barang meliputi menambah, mengubah, mencari dan menghapus data barang. Admin dapat mengelola data merk meliputi menambah, mengubah, mencari dan menghapus data merk. Admin dapat mengelola transaksi penjualan meliputi menambah atau membatalkan transaksi penjualan, mencetak struk transaksi penjualan, menyimpan dan menjurnalkan transaksi penjualan. Admin dapat mengelola laporan penjualan dan pnerimaan kas meliputi menampilkan dan mencetak laporan berdasarkan periode yang dipilih.

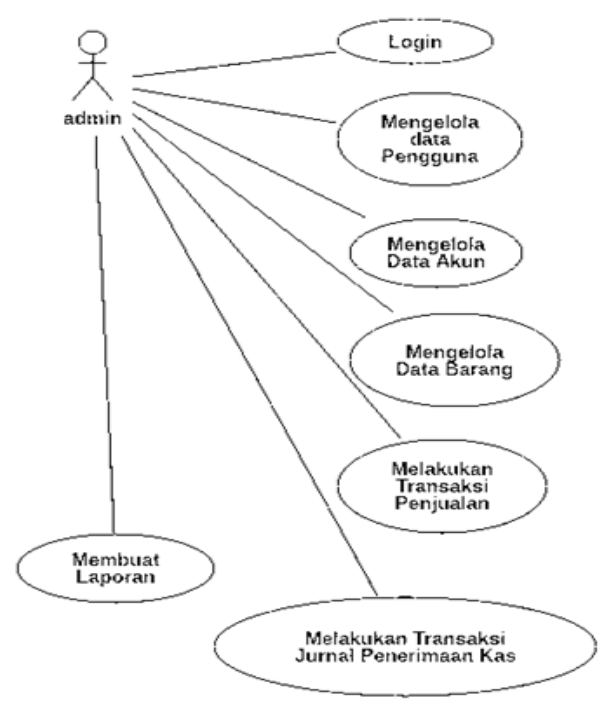

Gambar 3. Use Case Diagram Sistem Informasi Akuntansi Penjualan 


\section{Modelling}

Pada tahapan modelling dilakukan pengambarkan sistem informasi yang akan dibangun dengan menggunakan diagram UML. Berikut Use Case Diagram dari sistem informasi akuntansi penjualan. Pada Gambar 3 dijelaskan bahwa sistem dapat melakukan beberapa fungsi, yakni meakukan login ke aplikasi, mengelola data pengguna, mengelola data barang, mengelola data akun, melakukan transaksi penjualan, melakukan transaksi jurnal penerimaan kas dan membuat laporan.

Aktivitas yang dilakukan dalam satu use case yakni use case login pada Gambar 4. Activity diagram login dimulai dari admin menginput username dan password kemudian mengklik tombol login, dan sistem melakukan pengecekan terhadap username dan password yang diinput jika valid sesuai dengan database maka admin dapat masuk ke halaman menu utama jika tidak maka tampil pesan kemudian diminta untuk mengulang kembali proses login.

Gambar 5 menjelaskan aktivitas dari use case mengelola data pengguna. Activity diagram pengguna dimulai dari melakukan login dan melakukan penambahan, penghapusan dan pengupdaten. Gambar 6 merupakan activity diargram mengelola data barang. Activitas yang dilakukan meliputi menambah, menghapus dan mengedit data barang. Gambar 7 menjelaskan aktivitas dari usecase mengelola data akun perkiraan. Proses yang bisa dilakukan adalah menambah, mengubah dan menghapus data-data perkiraan untuk keperluan transaksi jurnal.

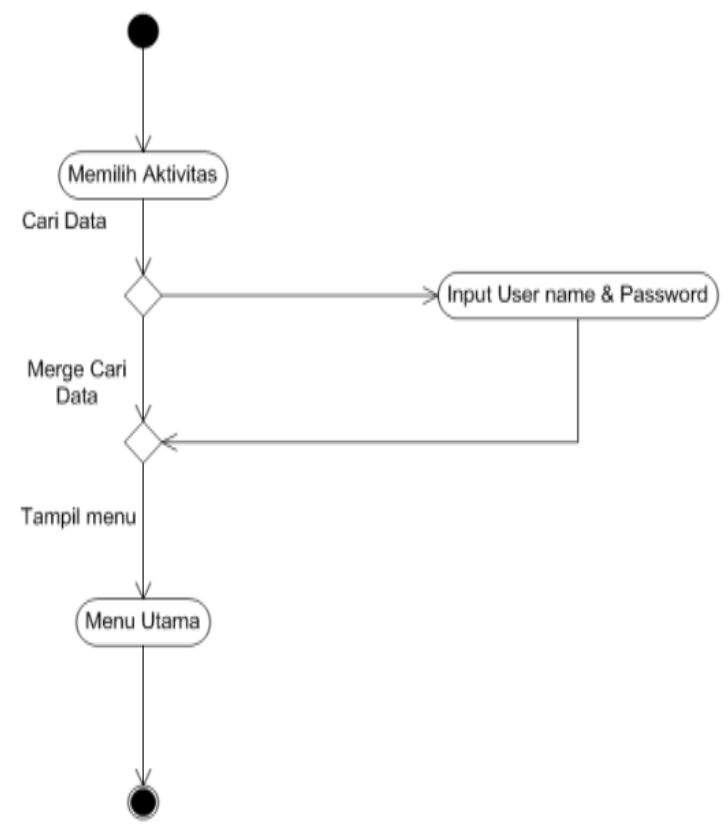

Gambar 4. Activity Diagram Halaman Login
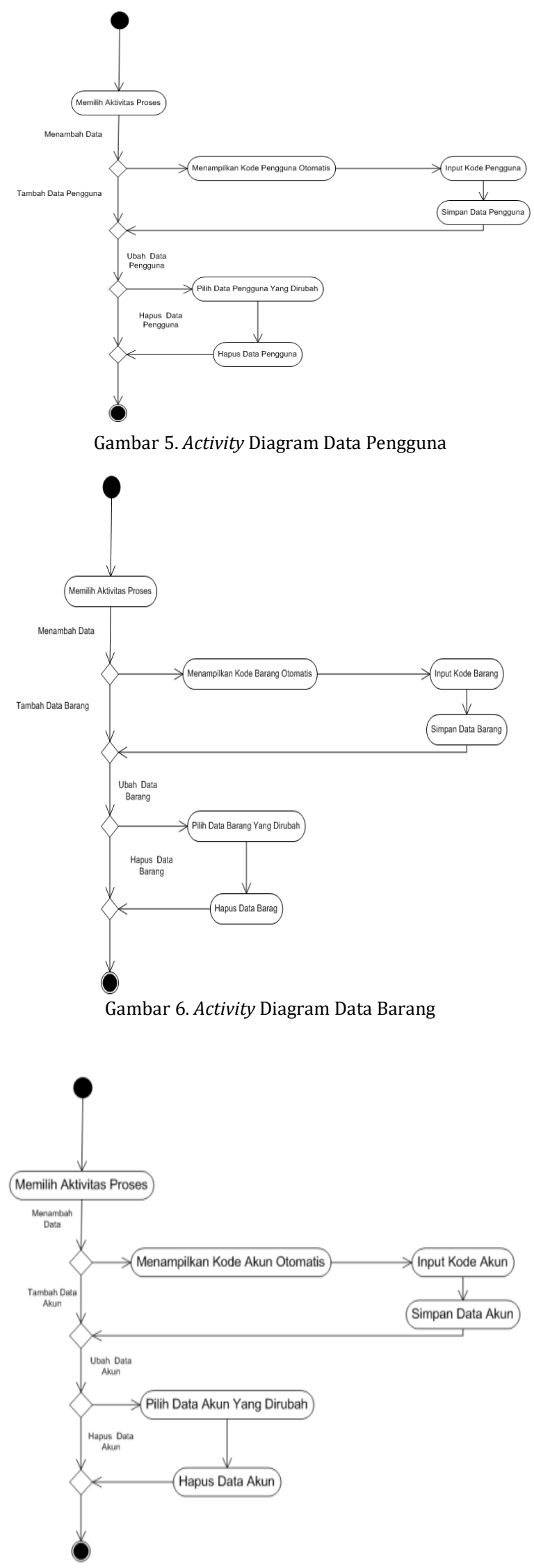

Gambar 7 Activity Diagram Data Akun 

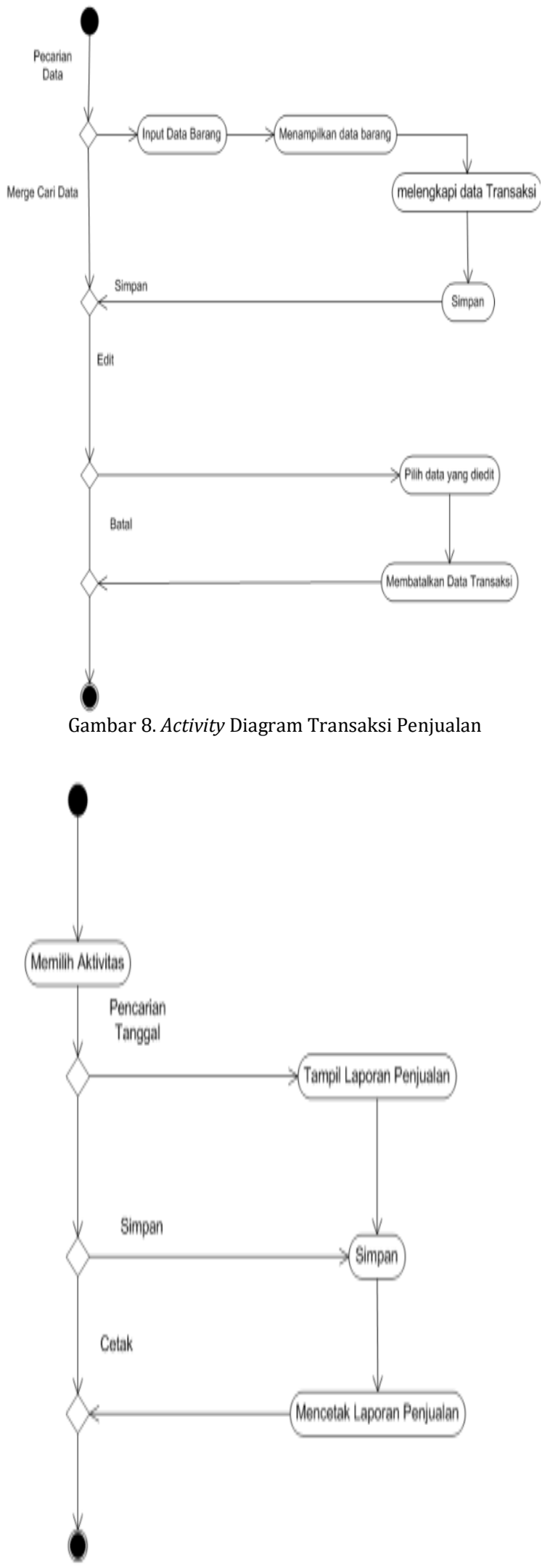

Gambar 8 Activity Diagram Laporan

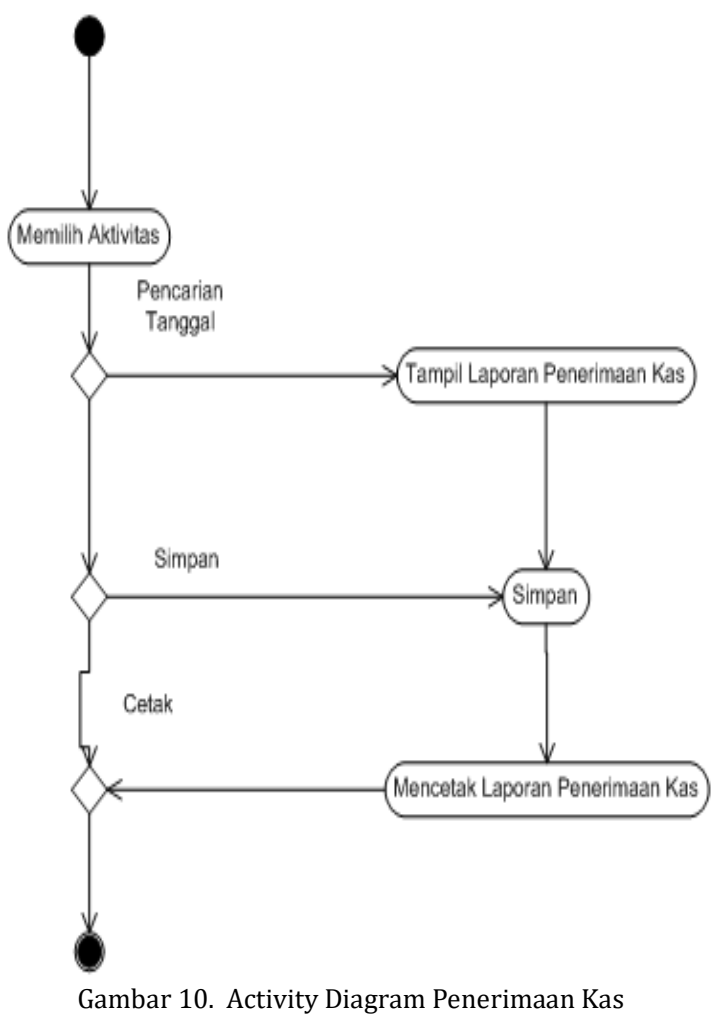

Gambar 8 merupakan activity diagram transaksi penjualan, menjelaskan aktivitas apa saja yang dilakukan dalam transaksi penjualan. Gambar 9 merupakan activity diagram membuat laporan. Activity yang ada menjelaskan apa saja yang harus dilakukan dalam kegiatan membuat laporan. Dimulai dari mengklik tombol laporan, pilih tanggal dan cetak laporan. Gambar 10 menjelasakan kegiatan apa saja yang dapat dilakukan oleh user dengan sistem dalam penerimaan kas. Activitas dimulai saat memilih tombol penerimaan kas dan memilih tanggal laporan yang ditampilkan.

D. Contruction

Pada tahapan ini dilakukan pembuatan aplikasi program yang diinginkan serta melakukan testing terhadap program yang dibuat. Pada tahapan ini dibangun form-form yang dibutuhkan oleh sistem informasi akuntansi penjualan dan dibuatkan blackbox testing untuk melakukan pengecekan coding program yang dibuat. Berikut user interface yang digunakan. Gambar 11 merupakan gambar form login dari sistem informasi akuntansi penjualan. Halamn login digunakan untuk verifikasi pengguna sehingga hanya pengguna yang terdaftar yang bisa menjalankan aplikasi. Halaman login terdiri dari input username dan input password kemudian klik tombol login.

Setiap pengguna baru yang akan menggunakan sistem maka wajib didaftarkan dulu kedalam form pengguna (Gambar 12). Pada form 
pengguna dapat melakukan penambahan, pengubahan, penghapusan data pengguna. Setiap barang yang akan dijual oleh Aexon Photo Copy dan Studio akan diberikan kode barang. Kode barang bersifat unik sehingga mudah dilakukan pencarian barang. Pada form barang pada Gambar 13 terdapat tombol tambah, hapus dan edit data. Halaman data akun pada Gambar 14 digunakan sebagai interface untuk mengelola data akun yakni data master perkiraan yang akan digunakan pada transaksi jurnal. Gambar 15 merupakan tampilan user interface dari form transaksi penjualan. Setiap terjadi transaksi penjualan di rekam dalam form transaksi penjualan. Tanggal dan username muncul otomatis. Dalam form transaksi penjualan disediakn tombol tambah, batal dan tutup.

Pengujian atau testing coding program dilakukan dengan menggunakan black box testing. Black box Testing disajikan Tabel 1.

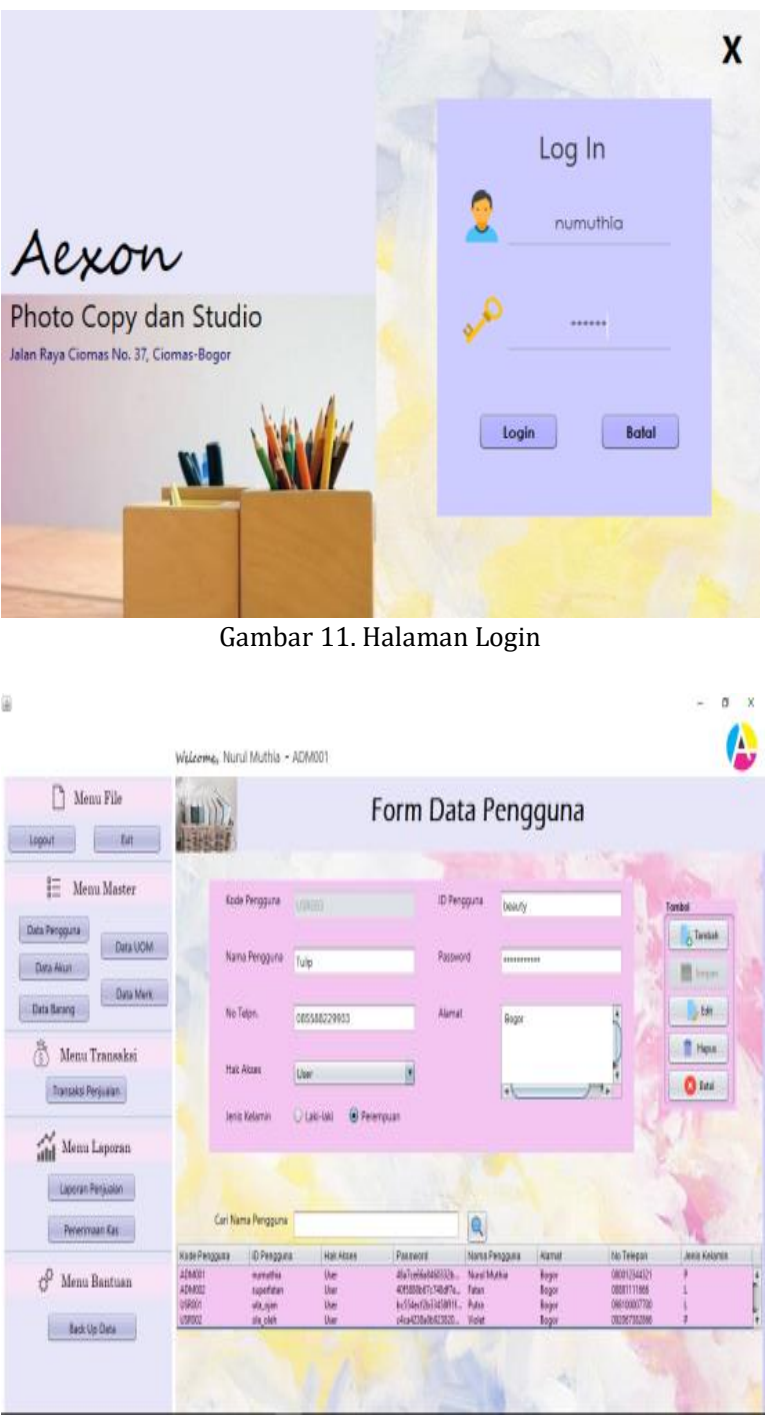

Gambar 12. Halaman Form Data Penguna

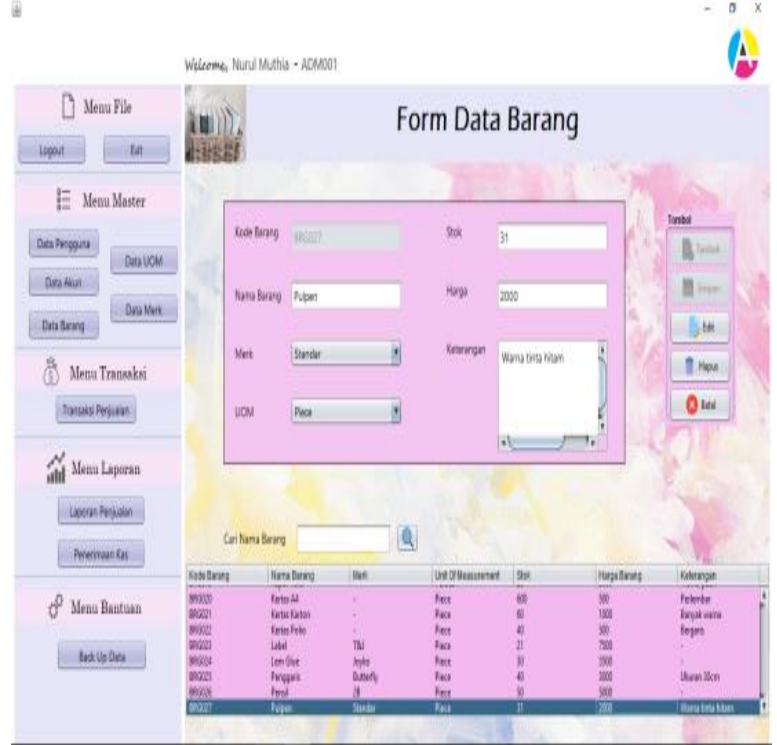

Gambar 13. Halaman Form Data Barang A

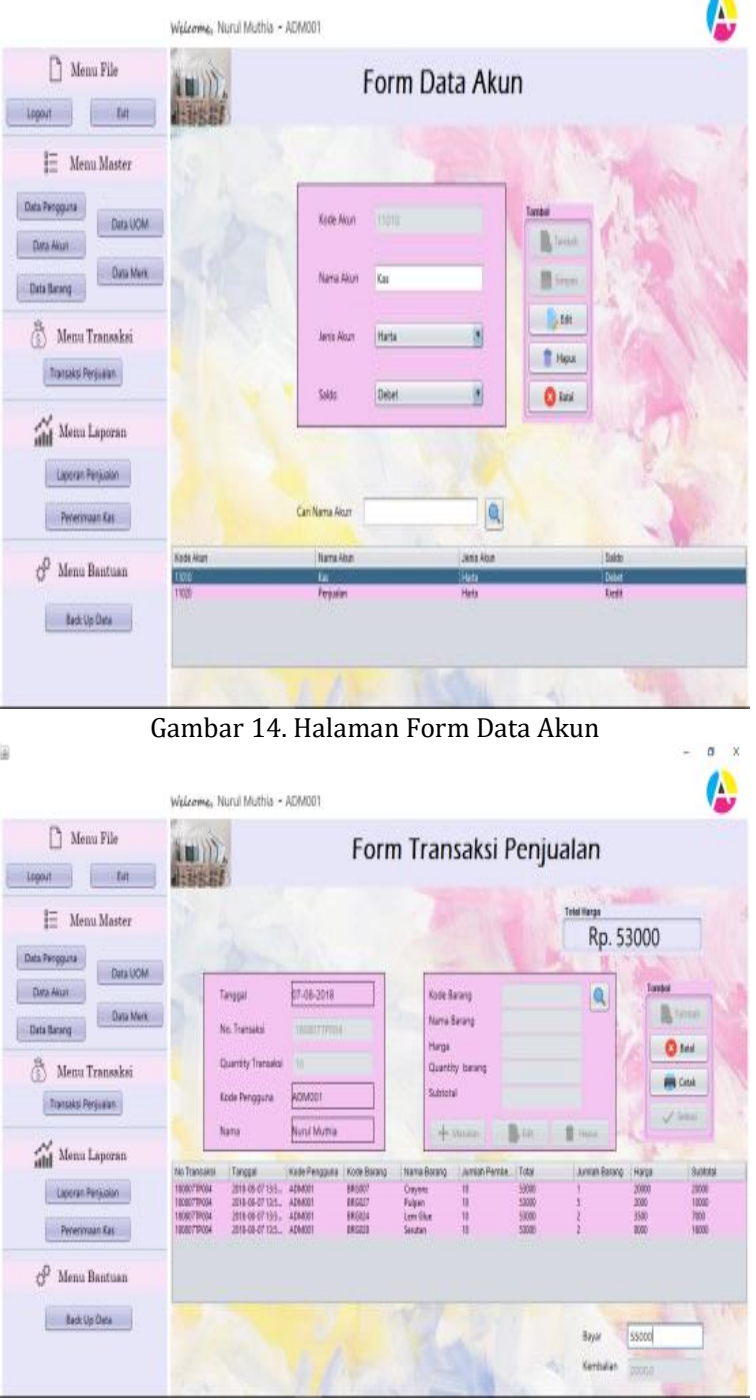

Gambar 15. Halaman Form Transaksi Penjualan 


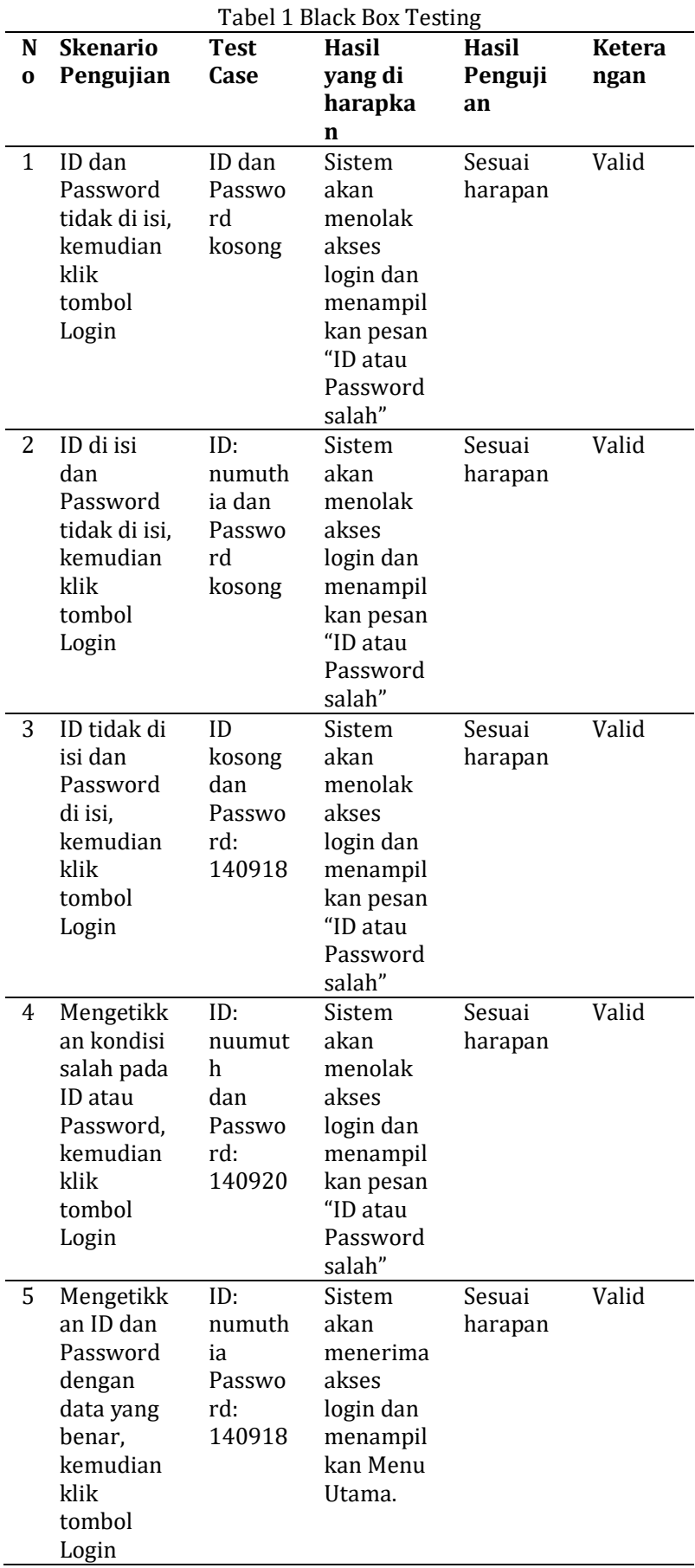

\section{E. Deployment}

Pada tahapan ini software dikirimkan kepada pengguna untuk dievaluasi. Pada tahapan ini digambarkan deployment diagram. deployment diagram (Gambar 16) sistem aplikasi informasi akuntansi penjualan menggunakan tools yang digunakan yaitu netbeans IDE 8.1, database MySQL dengan nama database photocopy.

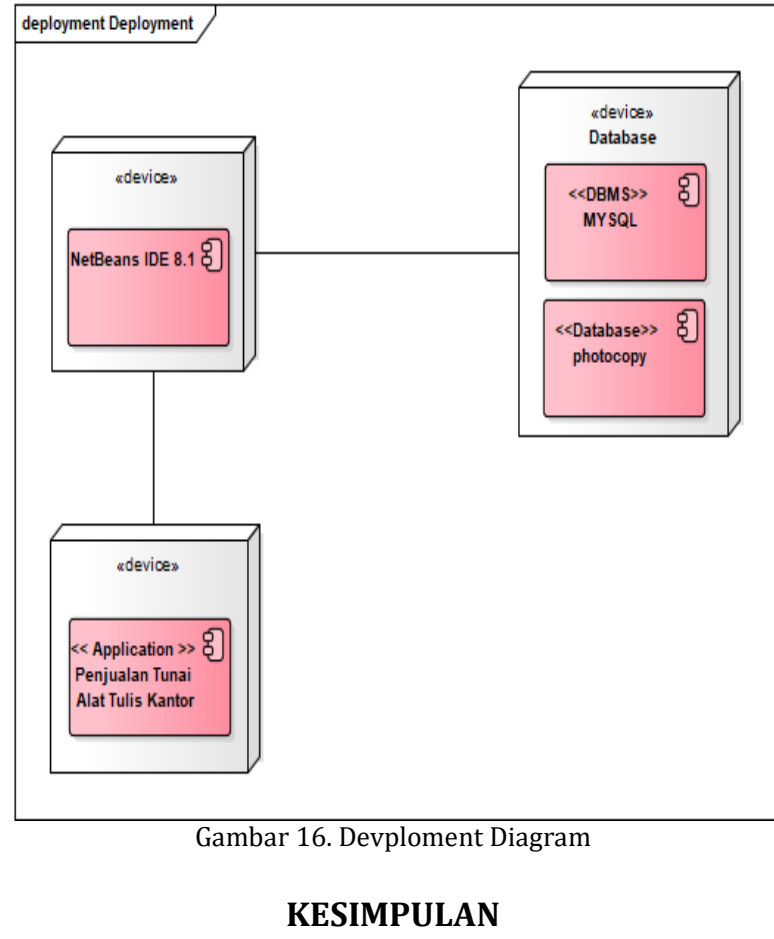

Rancang bangun sistem informasi penjualan dengan menggunakan metode waterfall ini mampu menyelesaikan permasalahan yang dialami oleh pengolahan data transaksi penjualan yang dilakukan secara manual. Dengan menggunakan sistem informasi penjualan ini badan usaha dapat mengurangi kesalah-kesalahan yang disebabkan oleh faktor manusia (human error), menghindari dari kerangkapan entry data dan penyajian laporan penjualan disajikan dalam waktu yang cepat dan tepat sehingga membantu pemilik untuk melakukan proses pengambilan keputusan yang tepat bagi perusahaannya. Sistem informasi penjualan dapat menjadi solusi bagi permasalahan yang dihadapi oleh sistem informasi penjualan manual. Pengembangan perangkat lunak yang menggunakan metode waterfall membuat pembangunan perangkat lunak menjadi efisien dan efektif untuk badan usaha yang tidak terlalu besar. Sistem Informasi Penjualan dapat meningkatkan efektivitas dan efisiensi pengolahan data, serta keamanan data lebih baik sehingga meningkatakn tingkat kepercayaan pembeli.

\section{REFERENSI}

Amalia , H., Ferdira, R., \& Anggaraini, M. (2017). Sistem Informasi Pengolahan Dana Donasi . Prespektif, 1-6.

Amalia, H., Lestari, A. F., \& Puspita, A. (2017). Penerapan Metode SVMBerbasis PSO 
Untuk Penentuan Kebangkrutan Perusahaan. 131-136.

Azwanti, N. (2017, Februari). Sistem Informasi Penjualan Tas Berbasis Web Dengan Pemodelan UML. Kumpulan Jurnal Ilmu Komputer, 01, 1-14.

Hasan, N. (2014). Perancangan Aplikasi Ecommerce Penjualan Komputer pada TOko Mitra Purworejo Menggunakan Php dan MySql. Bainlala Informatika, 81-88.

Ichsan. (2013, November). Sistem Pendukung Keputusan Pemilihan Penerima Beasiswa Mahasiswa Kurang Mampu Pada STMIK BUDIDARMA Medan Menerapkan Metode Profile Matching. Kursor, 5(1), 2.

Ishak, R., \& Widyastuti, H. (2018). Rancang Bangun Sistem Informasi Penjualan Kue Dan Roti Berbasis Web Pada Yuki Bakery. Swabumi, 27-34.

Muthia, N., Amalia, H., Puspita, A., \& Lestari, A. F. (2019). Laporan Penelitian Mandiri.

Pressman, R. S. (2010). Software Engineering A Practitioner's Approch. new york: McgrawHill.

Ramadhan, F., \& Purwandari, N. (2018). Sistem Informasi Penjualan Berbasis Web Pada PT Mustika Jaya. Kalbiscientias, 42-57.

Susanti, M. (2016). Perancangan Sistem Informasi Akademik Berbasis Web Pada SMK Pasar MInggu Jakarta. Informatika, 91-99.
Widayanti, R., Ariebowo, B., \& Maknunah, J. (2018). Sistem Informasi Penjualan Pada Toko Hagas Tani Batu Malang. SMATIKA, 50-55.

Widiati, W. (2017). Aplikasi Pengolahan Data Koperasi SImpan Pinjam Untuk Meningkatkan Pelayanan Koperasi. IJSEIndonesian Journal on Software ENgineering, 44-53.

Wijaya, D., \& Irawan, R. (2018). Prosedur Administrasi Penjualan Bearing Pada Usaha Jaya Teknika Jakarta Barat. 30-35. 